\title{
THERMAL INSULATION OF SINGLE LEAF FIRE DOORS Test results comparison in standard temperature-time fire scenario for different types of doorsets
}

\author{
Daniel Izydorczyk Bartłomiej Sędłak, Paweł Sulik \\ Building Research Institute, Fire Research Department, Ksawerów 21 St., 02-656 Warsaw, Poland
}

\begin{abstract}
Fire resistant door assemblies (doors) for pedestrian or industrial traffic with frame, leaf or leaves, rolled or folded curtain etc. are designed for installation in the openings of the building's vertical internal partitions. The building and its associated equipment shall be designed and made so that in case of fire it ensures the necessary load bearing capacity of the structure for the time specified in national regulations, limitation of fire and smoke propagation within the building, limitation of fire propagation onto the adjacent buildings and evacuation of people, and it provides safety of the rescue teams. The mentioned requirements are not usually considered individually (e.g. ensuring proper evacuation is connected with the structural load bearing capacity, fire and smoke propagation within the building, and rescue team safety), therefore individual elements of buildings can play several roles during a fire.

This also refers to the building elements such as doors which are usually required in terms of design and execution to ensure that in case of fire they shall, for a specific period of time prevent its development from the room or a specific zone where the fire started to other rooms or zones, allow evacuation of people by limiting heat radiation, and facilitate rescue team activities. Therefore, fire doors have a major role in the fulfillment of the rules of buildings fire safety.

This paper discusses the main issues related to the fire resistance of fire doors (tests methodology and way of classification) and presents a comparison of temperature rises on unexposed surface of fire doors test specimens depending on the type of structure and side of fire exposure. Temperature rises have been compared on unexposed surface of timber, aluminum and steel single leaf doorset which have fulfill the requirements of the $\mathrm{EI}_{2} 30$ fire resistance class, in case of the fire acting from the hinge side and the side opposite to the hinges.
\end{abstract}

Keywords: fire doors, fire resistance, integrity, insulation

\section{INTRODUCTION}

Fire doors are used as a hole closings in horizontal fire protection partitions usually used in a public facilities, such as hospitals, cinemas, schools and shopping malls. These buildings have to be constructed in a way to allow for an efficient and safe evacuation of all the people inside, in case of a fire. (Izydorczyk et al., 2014) Fire doors play a key role in meeting this requirement. In case of a fire, they are a barrier against fire, smoke and high temperature and therefore, they have to have an adequate fire resistant class (including fire integrity and fire insulation) and smoke barrier class. This paper discusses in more detail one of the aspects related to the heat transfer resistance, namely fire insulation.

\section{TECHNICAL SOLUTIONS}

Worldwide, there are many fire doors producers, hence the diversity of the product is vast. Despite the fact that each of them uses its own, individual design approaches, the common characteristics can be found in most of the cases. Firstly, the sole basis is a material the doors are made from, which can be wood or metal (usually aluminium or steel) (Sulik et al., 2015). Secondly, the type of the doors depends on the way they open (hinged, sliding, rolling shutters, etc.) and the number of door leaves (single leaf, double leaf door etc.). In addition, there is a particular type made from special fire protection glass. The below article focuses on the construction of the most common 
types of doors, namely solid timber doors and timber, glazed doors, steel doors and metal (steel and aluminium) profile doors.

Example profile cross-sections are presented in fig. 1


Fig. 1 An exemplary cross-sections of the steel and timber profile (Izydorczyk et al., 2014)

\section{FIRE RESISTANCE TESTS AND CLASSIFICATION}

Fire resistance class of doors cannot be calculated or assessed based on comparisons. The sole method allowing to obtain a realistic and clear classification of a specific element is the fire resistance testing. According to standard EN 13501-2:2007+A1:2009, the classifications of fire resistance doors shall be developed based on the tests carried out in accordance with standard EN 1634-1: 2014 (fire integrity assessment (E), fire insulation assessment (I), and radiation assessment (W)), and the tests carried out in accordance with standard EN 14600:2005 (self-closing feature assessment $(\mathbf{C})$ ).

The following fire resistance classes are defined:

Table 1 Fire resistance classes (Sędtak., 2012)

\begin{tabular}{|l|l|l|l|l|l|l|l|l|l|}
\hline $\mathrm{E}$ & 15 & 20 & 30 & 45 & 60 & 90 & 120 & 180 & 240 \\
\hline $\mathrm{EI}_{1}$ & 15 & 20 & 30 & 45 & 60 & 90 & 120 & 180 & 240 \\
\hline $\mathrm{EI}_{2}$ & 15 & 20 & 30 & 45 & 60 & 90 & 120 & 180 & 240 \\
\hline $\mathrm{EW}$ & & 20 & 30 & & 60 & & & & \\
\hline
\end{tabular}

(E - fire integrity, $\mathbf{I}$ - fire insulation, $\mathbf{W}$ - radiation)

Heating of the tested element is carried out according to the standard temperature/time curve. This relationship is the model of a fully developed fire in a room, and is described with $E q$. (1).

$$
\mathrm{T}=345 \log _{10}(8 \mathrm{t}+1)+20
$$

During the fire resistance testing of timber doors, the following performance efficiency criteria are verified:

- Fire integrity (denoted with the symbol $\mathbf{E}$ ) is the ability of the structure element that acts as a partition to withstand fire applied at one side, without transferring the fire to the unexposed side as a result of flame or hot gas penetration to the other side.

- Fire insulation (denoted for the doors with symbols $\mathbf{I}_{\mathbf{1}}$ or $\mathbf{I}_{2}$ ) is the ability of the structure element to withstand fire applied at only one side, without transferring the fire to the unexposed side as a result of significant heat transfer from the heated side to the unheated side.

- Radiation (denoted with the symbol $\mathbf{W}$ ) is the ability of the structure element to withstand action of fire applied at only one side, to limit the possibility of transferring fire as a result of significant heat radiation by the element or by its unexposed surface to the nearby materials. The elements for which the radiation criterion has been assessed shall be identified by adding the symbol $\mathbf{W}$ to the classification (e.g. EW). Classification of such elements shall be 
expressed in the time for which the maximum value of radiation, as measured using the method given in standard EN 1363-2:1999, does not exceed the value of $15 \mathrm{~kW} / \mathrm{m}^{2}$. It is assumed that the element which meets fire insulation properties $\mathbf{I}_{\mathbf{1}}$ or $\mathbf{I}_{\mathbf{2}}$ also meets the $\mathbf{W}$ requirements for the same period of time.

The fire resistance test shall be performed based on the carefully selected test sample, which shall be defined by the laboratory and subjected to a comparison between the field of application given by a principal and the field of application as defined by the test standards. These standards define in detail the way the test shall be performed, as well as give the principal some indications on how to achieve the widest field of application to be described first in the classification and then in the technical approval (TA). Before the test, the principal shall lay down the field of application of the element, which then will be included in the classification. This will determine: the construction of test samples, the type of mounting structure in which the door will be installed, the type of hardware fittings selected and the number of necessary tests to be carried out in order to obtain the expected range. The door's sample subjected to the fire tests has to be identical with the actual door used in practise. As the doors are required to be classified in terms of the fire resistance in both sides, the test shall include two samples (one for each of the side), unless the elements are fully symmetrical i.e. identical on the two sides of the axis of symmetry of the cross-sectional thickness (Sulik et al., 2014).

\section{THE TEMPERATURE RATES-OF-RISE COMPARISON AS DEPENDING ON THE DOOR CONSTRUCTION AND THE SIDE EXPOSED TO THE FIRE}

The comparison was made for 5 types of single leaf fire door with declared fire resistance class of $\mathrm{EI}_{2} 30$ that has been tested by Building Research Institute, Fire Research Department in the last years. The below sample elements were compared:

- aluminium, profile, glazed door - door leaf dimensions (width $\mathrm{x}$ height $\mathrm{x}$ thickness): $1400 \times 2400 \times 84 \mathrm{~mm}$, made of 3-chamber aluminium profile, central chamber was filled with insulation insert; door frame was made of the same profile as the door leaf;

- steel, profile, glazed door - door leaf dimensions (width $\mathrm{x}$ height $\mathrm{x}$ thickness): $1400 \times 2400 \times 80 \mathrm{~mm}$, made of 1-chamber steel profile, profile chamber was completely filled with insulation insert; door frame was made of the same profile as the door leaf;

- steel, solid door - door leaf dimensions (width x height x thickness): 950 x 2400 x $68 \mathrm{~mm}$, made of steel sheet, thick of $0,6 \mathrm{~mm}$, door leaf was filled with timber frame and mineral wool; door frame dimensions: $50 \times 100 \mathrm{~mm}$, door frame was made of steel sheet (thick of $1 \mathrm{~mm}$ ) and filled with cement mortar;

- timber, solid door and steel frame - door leaf dimensions (width $\mathrm{x}$ height $\mathrm{x}$ thickness): $1140 \mathrm{x}$ $2130 \times 40 \mathrm{~mm}$, door leaf was filled with timber frame and mineral wool and covered from both side HDF plates, frame dimensions: $50 \times 100 \mathrm{~mm}$, door frame was made of steel sheet (thick of $1 \mathrm{~mm}$ ) and filled with cement mortar;

- timber, solid door and timber frame - door leaf dimensions (width $\mathrm{x}$ height $\mathrm{x}$ thickness): 1200 x 2500 x $50 \mathrm{~mm}$, door leaf was made of high density special chipboard and covered from both side HDF plates; door frame dimensions: 50 x $100 \mathrm{~mm}$, door frame was made of pine timber.

All of the doors listed above, except the last, were tested in the case of the fire exposure on the hinges side and the side opposite to the hinges. The average temperature rises on the surface of the door leaf and frame measured by the thermocouples as distributed on the Fig. 2 are compared. 


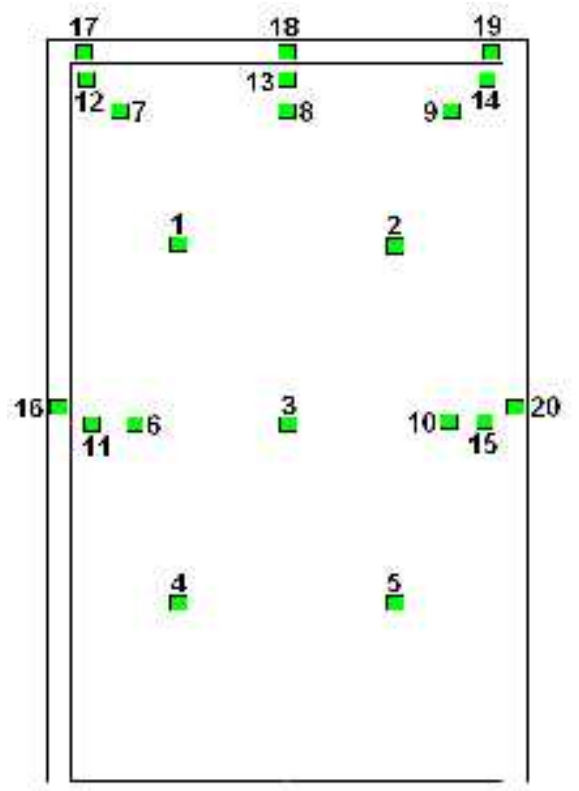

Fig. 2: The distribution of the thermocouples on the unexposed surface of the test sample

Fig. 3 illustrates the comparison of the average temperature rates-of-rise on the door-leaf surface (the average of the $1 \div 15$ thermocouples indications). Fig. 4 illustrates the comparison of the average temperature rates-of-rise in the distance of $25 \mathrm{~mm}$ from the visible edge of the door-leaf (the average of the $11 \div 15$ thermocouples indications) - in case of the aluminium and steel profile doors these were the only thermocouples placed on the door leaf profiles. Fig. 5 illustrates the comparison of the average temperature rates-of-rise on the door frame surface (the average of the $16 \div 20$ thermocouples indications)



Fig. 3 The comparison of the average temperature rates-of-rise on the door-leaf surface 




Fig. 4 The comparison of the average temperature rates-of-rise on the door-leaf surface, $25 \mathrm{~mm}$ from the visible edge of the leaf

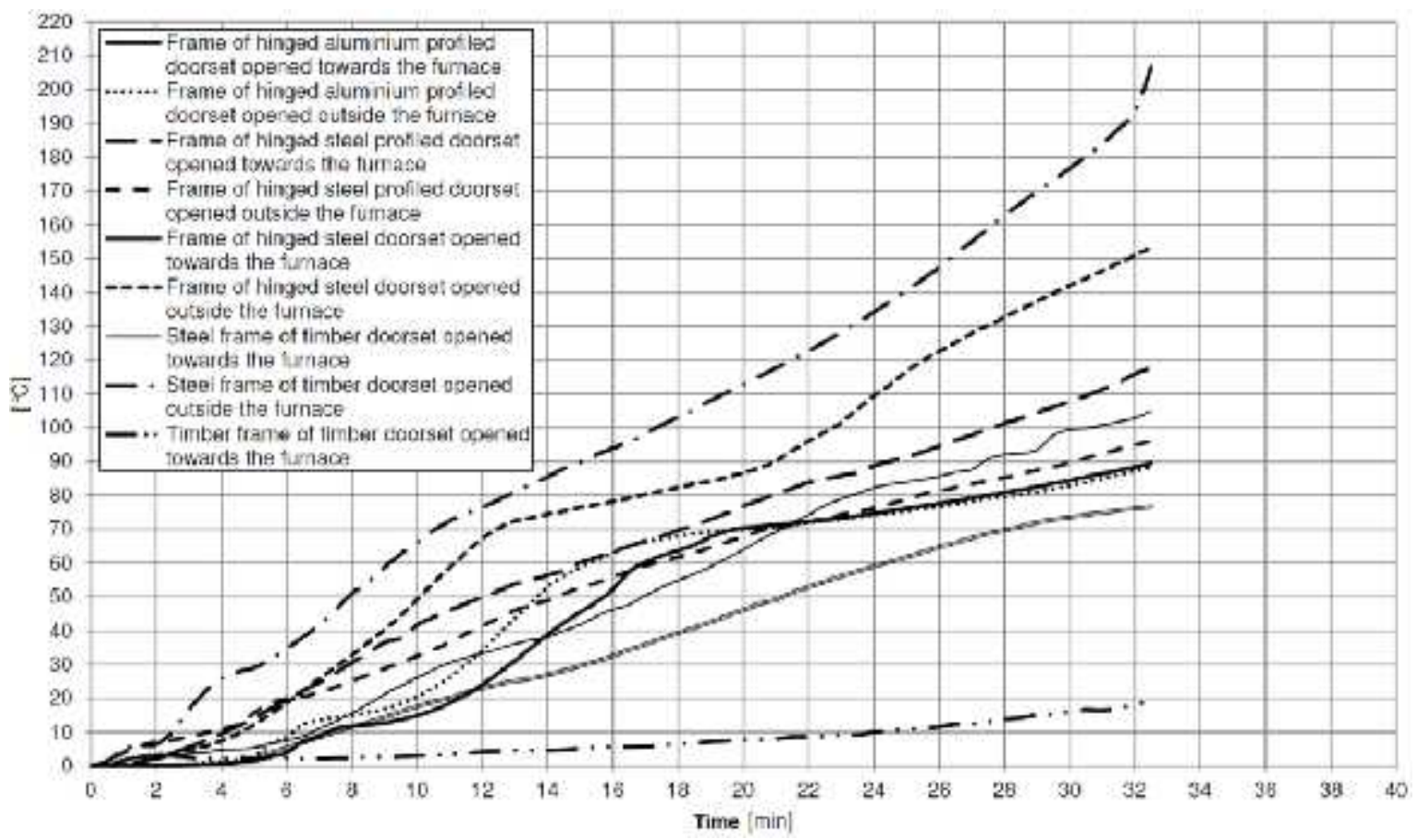

Fig.5 The comparison of the average temperature rates-of-rise on the door frame surface

\section{CONCLUSIONS}

Fire insulation of fire doors depends on the variety of factors related to both the design and the method of mounting. The materials used to produce the door-leaf as well as door frame are also crucial. Based on the analysis of the Fig. $3 \div 5$ one can observe how strongly the fire insulation is influenced by the side which has been exposed to the fire. Only timber door in a steel door frame showed a worse insulation when exposed to the fire on the hinge side for both the door leaf surface and the surface of the frame. In case of the steel profile door and steel door-leaf surface, the worst option for fire insulation is when the fire appears on the side of the door hinges. In the case of 
profiled steel door frame and steel door frame reverse phenomenon can be observed - much higher temperature rates-of-rise were registered on the door frames opening outwards the furnace. The temperature rates-of-rise on the surface of the door leaf and the door frame of the aluminium profile door when opening both outwards and towards the furnace were so similar that no unequivocal conclusion can be made determining which direction of the fire is, in this case, worse. It is impossible to assess the fire resistance class or the actual insulating of the fire doors based on their design or the specification of the component materials. Even a slight change in the structure or the method of mounting can significantly affect their characteristics associated with the resistance to fire. The only way to determine the actual fire resistance class is therefore to perform an adequate test. It is important to emphasize that the fire insulation class is interconnected with the fire integrity class and hence classifying the door just in terms of fire insulation is not possible. This is why also the fire integrity loss always occurs together with the fire insulation loss.

\section{REFERENCES}

Izydorczyk D., Sędłak B., Sulik P. 2014. Fire Resistance of timber doors - Part I: Test procedure and classification, Annals of Warsaw University of Life Sciences - SGGW Forestery and Wood Technolog, No. 86, 125-128.

Izydorczyk D., Sędłak B., Sulik P. 2014. Fire Resistance of timber doors - Part II: Technical solutions and test results, Annals of Warsaw University of Life Sciences - SGGW Forestery and Wood Technology, No. $86,129-132$.

Izydorczyk D., Sędłak B., Sulik P. 2014. Problematyka prawidłowego odbioru wybranych oddzieleń przeciwpo arowych, Materiaty Budowlane, $\mathrm{nr}$ 11, 62-64.

Sędłak B. 2012: Metodyka badań odporności ogniowej drzwi przeszklonych. Cz. 1, Świat Szkła, R. 17 (nr 3), $50-52,60$

Sędłak B. 2012. Metodyka badań odporności ogniowej drzwi przeszklonych. Cz. 2, Świat Szkła, R. 17 (nr 4), $55-58,60$

Sulik P., Sędłak B. 2015. Prawidtowy odbiór przeszklonych drzwi przeciwpo arowych, Świat Szkt, R. 20 (nr 2).

Sulik P., Sędłak B., Izydorczyk D. 2014. Odporność ogniowa i dymoszczelność drzwi przeciwpo arowych na wyjściach awaryjnych z tuneli-badania i klasyfikacja, Logistyka, nr 6, 10104-10113. 